\title{
USE OF SOCIAL MEDIA AND ELECTRONIC SOURCES FOR RECEIVING INFORMATION IN REHABILITATION OF MS PATIENTS
}

\author{
Evis Allushi $^{1 *}$, Gentian Vyshka ${ }^{2}$, Vasilika Prifti ${ }^{3}$ \\ ${ }^{1 * 3}$ University "Ismail Qemali” of Vlora, Department of Nursing, Vlora, Albania; \\ ${ }^{2}$ University of Tirana, Medicine Faculty, Tirana, Albania; \\ Corresponding Author Evis Allushi, e-mails: evis.allushi@univlora.edu.al;
}

Received August 2020; Accepted September 2020; Published October 2020;

DOI: https://doi.org/10.31407/ijees10.414

\begin{abstract}
In our days health informatics has a great impact in management of patients with multiple sclerosis (MS). We evaluate three concrete case studies with MS in Vlore City, their knowledge about MS and the impact of rehabilitation in MS, the way and the sources from where they got the information and identifying barriers. This is a comparative study of three cases of patients with MS. The main part of the interview consisted on questions about the use of internet or medical webpages for getting information about their disease. The comparison of patients revealed that only one had information from the internet that had a major impact on the rehabilitation process while it was contrary to the others. The other two patients have not been able to obtain MS information either from social media or from other sources.
\end{abstract}

Keywords: multiple sclerosis, e-health, rehabilitation. 